\title{
Putting the French Duty of Vigilance Law in Context: Towards Corporate Accountability for Human Rights Violations in the Global South?
}

\author{
Almut Schilling-Vacaflor ${ }^{1}$ \\ Accepted: 19 October 2020/ Published online: 24 October 2020 \\ (C) The Author(s) 2020
}

\begin{abstract}
The adoption of the French Duty of Vigilance law has been celebrated as a milestone for advancing the transnational business and human rights regime. The law can contribute to harden corporate accountability by challenging the "separation principle" of transnational companies and by obligating companies to report on their duty of vigilance. However, the question of whether the law actually contributes to human rights and environmental protection along global supply chains requires empirically grounded research that connects processes in home and host state countries. This paper contributes to such a new research agenda by linking political ecology literature and empirical insights from the Global South to research on due diligence regulations. With reference to field research data on contestations between the oil and gas company Total $\mathrm{E} \& \mathrm{P}$ and indigenous communities in Bolivia, I argue that the burden of proof and contestations over valid knowledge represent major obstacles when trying to establish legal liability.
\end{abstract}

Keywords Due diligence $\cdot$ Extractive industry $\cdot$ Accountability $\cdot$ Burden of proof $\cdot$ France . Bolivia

\section{Introduction}

Transnational corporations (TNCs) nowadays account for half of global exports, almost one-third of GDP and about one-fourth of global employment (OECD 2018). Global commodity chains are often highly centralized, and only a few companies dominate the world market (Bridge and LeBillon 2017; Clapp 2018). However, these parent firms enjoy a limited legal liability, as there is a fundamental disjuncture between economic

Almut Schilling-Vacaflor

aschillingva@uni-osnabrueck.de

1 Institute of Social Sciences, Osnabrück University, Seminarstr. 33, 49074 Osnabrück, Germany 
reality and legal form (Ruggie 2018). National law for the most part governs the separate legal entities, not the single economic enterprise of parent and daughter companies, subsidiaries, and entities controlled by the parent firm. This principle of legal separation (or "separation principle") has been at the core of current discussions in the field of business and human rights (Mares 2020). The separation principle has enabled retail and brand companies to increasingly source goods from suppliers embedded in complex and often intractable commodity chains, whereby lead firms have maximized their profits while minimizing their liability (LeBaron et al. 2017).

This paper focuses on the globalized and highly centralized fossil fuel sector. Bridge and LeBillon (2017: 1) remind us that "oil pulses through our daily lives. It is the plastic we touch, the food we eat, and the way we move. Oil powers our cars, chainsaws and tanks." The fossil fuel sector has been the main emitter of global greenhouse gasses (IPCC 2014). The rising consumption of products based on fossil fuels by industrialized countries and emerging economies has casted a disproportionate share of the ecological shadows onto the world's most vulnerable ecosystems, poorest people, and future generations (Dauvergne 2010; Bridge and LeBillon 2017). I draw on extensive field research in indigenous communities with gas activities in Bolivia, outlining the human rights and environmental implications of this globalized sector in local places and pointing to the existence of important governance gaps.

Against this background, I analyze and discuss to what extent the first comprehensive and legally binding human rights due diligence regulation worldwide, the "Duty of Vigilance of Parent and Instructing Companies" law ("Duty of Vigilance law") adopted in France in 2017, could contribute to increasingly hold TNCs such as the French oil and gas giant Total accountable for their human rights and environmental performance in the Global South. This law has inspired activists and politicians across Europe to propose similar measures in other countries and at EU level, catalyzing 13 campaigns/ parliamentary motions for stringent legislation (Evans 2019; see also Palombo 2019).

This study draws on and aims to contribute to previous literature from the field of political ecology that has addressed the extractive industries and their negative externalities in Latin America (e.g., Bebbington and Bury 2013; Arsel et al. 2016; Leifsen et al. 2017) and to the literature on new public regulatory approaches in the ambits of human rights and sustainable development to hold corporations accountable for their impacts abroad (e.g., Bartley 2014; Moser and Leipold 2019; Partzsch 2020). These literatures have previously developed separately. However, for discussing the effectiveness of the French Duty of Vigilance law and similar initiatives that are currently underway in different European countries and at the EU level, it will be important to increasingly connect the analysis of the drafting and monitoring of due diligence laws in "home state countries" with their implementation on the ground in "host state countries." In line with Krajewski (2018), I define "home state countries" as the places where the headquarters of the mother firms are located, while human rights violations often occur in the places of production and transportation in other countries, the "host state countries."

Previous literature on new corporate accountability norms for regulating global commodity chains has largely departed from the assumption that the state's ability to set legally binding requirements can coerce companies into complying to a greater extent than private and mainly voluntary measures (Bartley 2014). However, empirically grounded research into previous mandatory supply chain regulations from the 
demand side has shown that the adopted norms have not necessarily contributed to 'hardened" accountability, i.e., more stringent regulations, better enforcement, and more democratic legitimacy (Moser and Leipold 2019; see "Hardening Corporate Accountability through Due Diligence Policies?"). In this paper, I draw on such previous research but also aim to extend it in two respects. First, here I analyze the potential and limitations of a law that has resulted out of yearlong struggles by social organizations and that has been celebrated as a particularly stringent and comprehensive regulation. Second, previous literature has mainly focused on dynamics from the demand side, such as the drafting, output, and monitoring of due diligence regulations, while here I establish connections between the French law and a specific place in the Global South.

The data for the Bolivian case study were collected through a total of 12 months of field research in Bolivia between 2013 and 2015, based on over 100 semi-structured interviews, several focus group discussions, the analysis of original documents, and participatory observation in community assemblies and prior consultation processes. I carried out field research in diverse indigenous Guaraní "captaincies"1 and communities of the Chaco region, where the large majority of Bolivia's gas reserves are located. In this study, I will focus mainly on the experiences of two Guaraní captainciesnamely, Parapitiguasu and Alto Parapeti-with the company Total E\&P, a daughter firm of the French parent firm Total. Total could now in theory be held accountable in France for human rights violations and environmental damages caused by the operations of its daughter firm in Bolivia. In addition, I conducted fifteen interviews with representatives from French and other European human rights and environmental NGOs about the Duty of Vigilance law and other mandatory supply chain regulations between February 2018 and February 2020. I anonymized interviews and analyzed the data with the software ATLAS.ti.

The remainder of the article begins with a short outline on the hardening of corporate accountability by new due diligence regulations. The following section provides information about tort-based litigation against TNCs; the "Protect, Respect, and Remedy" framework; and the UNGPs and then discusses the French Duty of Vigilance law, with a focus on the law's stringency and enforcement. "Indigenous Peoples' Rights and Hydrocarbon Extraction in Bolivia: the Case of TOTAL E\&P" describes the socioenvironmental impacts caused by Total E\&P in Guaraní communities in Bolivia and sheds lights on the related contestations. Thereafter, I discuss the potentials and limitations of the French Duty of Vigilance law to address the grievances of local communities in Bolivia and, more generally, in the Global South. The conclusions follow.

\section{Hardening Corporate Accountability Through Due Diligence Policies?}

Current governance arrangements are insufficient for addressing the negative impacts caused by powerful TNCs, especially in the Global South. Attempts to create binding international regimes or conventions for holding TNCs accountable for their human

\footnotetext{
${ }^{1}$ The term "captaincy" (capitanía) is a legacy from the colonial period. Captaincies are composed of local Guaraní communities and form larger subnational political-territorial entities.
} 
rights and environmental records abroad have previously failed, largely due to the fierce lobbying by TNCs and powerful business associations (Clapp 2005; Simons 2012; Ruggie 2018). In turn, also many states have resisted the adoption of international binding rules for enhancing corporate accountability. Ruggie (2018) explained the relative weakness of public international law in the ambit of business and human rights with the fact that states are economic actors themselves, for instance by promoting and attracting foreign investments. In the producing countries, many of them located in the Global South, a lack of state capacity, poor regulation, lax enforcement, corruption, or a too-close relationship between business and government have often hindered the protection of human rights and the environment (see Boyle 2012).

The emergence of private sustainability governance has been interpreted as a response to existing regulatory gaps and failed attempts to create binding international regimes or conventions (Cashore et al. 2004; Sikor et al. 2013). While private governance has often gone beyond mere window dressing, the limitations of voluntary approaches, such as a lack of legitimacy, limited uptake, weak auditing, and deficient forms of traceability, have been comprehensively discussed (e.g., Fuchs et al. 2011; Dauvergne and Lister 2012; Schleifer et al. 2019).

Against this background, the calls for "bringing the state back" into global governance and for hardening corporate accountability have become louder in the recent past (Bartley 2014; Lenschow et al. 2016; Craig 2017). For instance, Bartley (2014) argued that "hard transnational regulation" based on legally binding requirements and state-imposed sanctioning can contain companies' avoidance of rigid standards, regressing on commitments, and even survival of scandals with only minor damage. I draw on Grant and Keohane (2005: 29) to define accountability as a governance arrangement in which "[S] ome actors have the right to hold other actors to a set of standards, to judge whether they have fulfilled their responsibilities in light of these standards, and to impose sanctions if they determine that these standards have not been met."

Especially since the twenty-first century, we can observe the emergence of new human rights and environmental due diligence policies regulating supply chains in countries of the Global North. In Europe, the EU's regulation to eliminate illegal, unreported, and unregulated fishing (IUU regulation 2008), the EU's Renewable Energy Directive 2009/28/EC (EU-RED) (adopted in 2009 and revised in 2018), the European Union Timber Regulation (EUTR 2010), the UK Modern Slavery Act (2015), the EU's Conflict Minerals law (2017), the French Duty of Vigilance law (2017), and the Dutch Child Labor Due Diligence law (2019) were adopted.

While representing important steps for visibilizing and addressing the impacts of global commodity chains, the adopted regulations have been criticized for their lack of stringency, comprehensiveness, and enforcement (Moser and Leipold 2019; Partzsch 2020). For instance, based on the EUTR, companies cannot be held legally liable for noncompliance, but rather civil penalty fines are imposed on the responsible, typically administrative, personnel. Such fines tend to be low and ineffective when compared with the damages caused by trade with illegal timber (Partzsch 2020). The UK Modern Slavery Act exclusively establishes reporting duties and does not foresee sanctions for insufficient due diligence systems. More broadly speaking, EU legislation has largely embraced company reporting and private audit programs to determine corporations' compliance with mandatory rules, thereby enhancing (instead of controlling) private 
authority, certification, and the "audit regime' (Le Baron et al. 2017; Zajak and Scheper 2019). The audit regime has been criticized for being designed and implemented in ways that conceal problems rather than bringing them to light and for protecting industry interests (ibid.). With a focus on palm oil certification and land rights of local communities in Indonesia, Silva-Castañeda (2012) showed how the communities' land claims were disregarded in audits, while the formal documents presented by companies were considered valid evidence. Similarly, research into soy certification in Brazil found that auditing practices have been insufficient for meaningfully assessing the compliance of farmers with sustainability standards and in particular for protecting the access of local communities to land and water (Schilling-Vacaflor et al. forthcoming).

After this brief overview on new due diligence policies in general, I will focus more specifically on the United Nations' Protect, Respect, and Remedy (PRR) framework; the UNGPs; and the French Duty of Vigilance law.

\section{The UNPGs on Business and Human Rights and the French Duty of Vigilance Law}

\section{Tort-Based Litigation Against TNCs, the PRR Framework, and the UNGPs}

To differing extents, home state countries have made experiences with tort-based litigation against TNCs. The main forum for such lawsuits has been the USA, where courts have ruled on dozens of cases regarding overseas human rights violations of TNCs since the 1980s. Several of these cases involved indigenous communities taking action against corporations like Texaco-Chevron (Ecuador), Shell (Nigeria), or Rio Tinto (Papua New Guinea) (Gilbert 2012). However, in the recent past, it has become more difficult to file complaints concerning TNC's extraterritorial duties on human rights in the USA, while European jurisdictions have become more important as a venue for such complaints (see Wesche and Saage-Maaß 2016).

In particular, courts in the UK have appeared to be a relatively favorable forum for this kind of litigation. In 2019, the English Supreme Court ruled against the UKdomiciled company Vedanta and its Zambian subsidiary for environmental damage abroad. In this case, information made publicly available by Vedanta on the relationship between the mother company and its subsidiary as well as the judge's assumption that claimants could not obtain "substantial justice" in Zambia were key factors for accepting to handle the case in the UK (Bradshaw 2020). However, Bradshaw (2020: 146) warns that this case might actually lead companies to be more cautious with the voluntary disclosure of information in the future and he argues that "the battle for these particular claimants may have been won, but the war concerning jurisdiction over parent companies and their foreign subsidiaries is not over." More broadly speaking, literature on tort action cases on alleged human rights violations of TNCs abroad has comprehensively discussed existing procedural and practical challenges, such as the admission of cases in the courts of home state countries and the high costs that often arise in such transnational cases (Gilbert 2012; Wesche and Saage-Maaß 2016). Furthermore, given the structural asymmetry in information, claimants from countries in the Global South, often belonging to marginalized groups, have encountered great difficulties in proving their cases (Terwindt et al. 2018; Enneking 2019). The concrete 
"factual" disputes in lawsuits have often concentrated on chains of causality and on the responsibility of a mother firm regarding specific human rights and environmental impacts abroad (Shamir 2004).

Against the background of governance gaps and challenges to hold TNCs into account for their negative externalities, scholars and activists have lobbied for the adoption of stringent due diligence regulations, both at the international and domestic levels. In 1998, the "Working Group on Transnational Corporations" was established by the United Nations, and its main task was to draft an international mandatory regulation on business and human rights. However, the resulting "Norms on the Responsibilities of Transnational Corporations and other Business Enterprises with regard to Human Rights" were disapproved by the UN Commission of Human Rights in April 2004.

In July 2005, Kofi Annan appointed professor John Ruggie to be Special Representative of the UN Secretary-General on Business and Human Rights. Building on stakeholder and online consultations, Ruggie drafted the framework "Protect, Respect, and Remedy" (PRR) (2008), which rests on three pillars: (1) the state duty to protect against human rights abuses by third parties, including business; (2) the corporate responsibility to respect human rights; and (3) greater access by victims to effective remedy. The accompanying UNGPs were unanimously adopted by the UN Human Rights Council in 2011. Human rights due diligence is the central concept in the PRR framework and the UNGPs. In contrast to previously predominant corporate social responsibility (CSR) approaches, wherein voluntary commitments of companies and social audits have been key tools, human rights due diligence is explicitly based on a human rights framework (Terwindt and Saage Maaß 2016). The adoption of the PRR framework and of the UNGPs have been important steps to move from CSR to corporate accountability. Upon the adoption of the UNGPs, the Organization of Economic Co-operation and Development (OECD) revised its Guidelines for Multinational Enterprises to incorporate new standards that align with the UNGPs.

Ruggie deliberately avoided to focus the debates surrounding the UNGPs on the question of whether they should be voluntary or mandatory and outlined that the UNGPs do not create new normative standards but rather "elaborate the implications of existing standards and practices that are integrated within a single, logically coherent and comprehensive template" (Ruggie cit. after Addo 2014). This pragmatist approach was criticized by human rights organizations advocating for a stringent, legally binding treaty. In addition, a factor that seriously limits the effectiveness of the UNGPs is that these principles are embedded within an international legal system that enables corporate impunity for human rights violations. For instance, scholars have comprehensively discussed how WTO rules, bilateral investment treaties, free trade agreements, and host government agreements have restricted or undermined the protection of human rights (Eckersley 2004; Cottier et al. 2005).

The adopted principles on business and human rights have shifted the contestations about binding vs. voluntary rules on business and human rights to the domestic scale, by outlining that states should use a "smart mix" of voluntary and obligatory regulations for creating a level playing field for all corporations (United Nations Human Rights Office of the High Commissioner 2011: 5). The European Commission of the European Union called on all Member States to adopt a national action plan (NAP) for the implementation of the UNGPs by 2012. To date, most EU states already adopted 
such plans, but they are largely declaratory of existing measures and commitments, with few concrete measures to take effective action (O'Brien et al. 2016; Rivera 2019). In turn, with the exception of the French Duty of Vigilance law, adopted laws on due diligence obligations have had a rather narrow issue-specific focus (see "Hardening Corporate Accountability through Due Diligence Policies?").

\section{The French Duty of Vigilance Law}

France has been the only country to date to adopt a comprehensive law on human rights and environmental due diligence at 27 March 2017, entitled "Duty of Vigilance of Parent and Instructing Companies" (Law No. 2017-399). This law was the result of a 4year-long struggle of French NGOs and trade unions, together with three deputies of French Congress. The adoption of the law was enabled by a combination of conditions: the public outrage surrounding the "Rana Plaza" tragedy in 2013 (the collapse of a textile factory in Bangladesh that had close links with French companies); the French national political culture (widespread anticipation of state intervention; antiglobalization sentiment); a center-left government under previous President Hollande; and the appointment of a Minister of Economy and Industry in 2016 who was in favor of the law (Evans 2019; Petitjean 2019).

The Duty of Vigilance law applies to companies headquartered in France that employ at least 5000 employees in France, or 10,000 employees worldwide (including through direct and indirect subsidiaries) or foreign companies headquartered outside France, with French subsidiaries, if those subsidiaries employ at least 5000 employees in France. This law establishes the companies' duty of care, "a legal obligation to adhere to a standard of reasonable care, while performing any acts that could foreseeably harm human rights or the environment" (Cossart et al. 2017: 318). Those harmed may bring civil (tort) action and claim remedy. According to the law, the corporations have to implement vigilance plans, formulated with stakeholder participation, for the company's operations, as well as the operations of all the subsidiaries or companies it controls. The law also stipulates that the plans shall include reasonable vigilance measures to prevent human rights violations and environmental damage from the operations of the subcontractors or suppliers with whom it maintains an established relationship. The plan shall be published and include the following measures: a risk mapping, regular evaluation procedures, appropriate actions to mitigate risks or prevent severe impacts, an alert and complaint mechanism within the company, and a system to supervise the implementation of measures and evaluate their effectiveness. The law stipulates that companies that fail to publish or implement vigilance plans are subject to sanctions ("periodic penalty payments") and the parent company can be held liable if a harm has been caused by failure to properly implement an adequate plan ("civil liability action") (Brabant and Savourey 2017). While acknowledging the pioneering role of the French law to regulate TNCs, its limitations regarding stringency and enforcement also merit detailed discussion.

\section{Stringency}

The process to draft and adopt the Duty of Vigilance law was highly contested. Employers' organizations and business associations as well as conservative and liberal 
political forces fiercely resisted the adoption of the bill (Evans 2019). ${ }^{2}$ It has also been very challenging to convince the members of the former leftist government under president Hollande to support the adoption of the Duty of Vigilance law (interview with staff from a French human rights organization, 21 August 2019). The law went through four readings in the French National Assembly and three in the Senate during which the bill was weakened (Aïssi 2018).

A comparison of the original law proposal submitted to the presidency of the National Assembly in November 2013 and the law adopted in March 2017 reveals two important differences. ${ }^{3}$ First, the original proposal targeted all companies based in France and not just the ones above a certain threshold of employees. Second, the initial proposal provided for a reversal of the burden of proof from victims to companies. Concretely, the original proposal stipulated: “The enterprise's liability, under the conditions defined above, is engaged unless it proves that it could not [...] prevent the damage by putting an end to its risk or by preventing its realization, taking into account the power and means at its disposal" (Auroi et al. 2013; author's English translation). In contrast, according to the adopted law, only if it can be proven that a company breached its obligations outlined in the law, the company is liable for any damage that the execution of these obligations could have prevented (Sherpa 2019). As outlined above and taken up in the discussion, the issue of the burden of proof has been of crucial importance in litigation cases against TNCs and will likely be an important barrier in the enforcement of the law.

After the bill's adoption, 120 right-wing and liberal legislators from both chambers referred the bill to the Constitutional Council, on grounds of alleged unconstitutionality regarding companies' freedom to trade and do business. The Council ruled that the bill was in general consistent with the constitution, even though it censured the possibility of imposing a civil fine of up to thirty million Euro.

\section{Enforcement}

To date, implementation and enforcement of the Duty of Vigilance law have been weak. France's President Macron who acted as Minister of the Economy and Industry between 2014 and 2016 has been an outspoken adversary of mandatory rules on business and human rights. His government's negative attitude towards the law has manifested in a lack of state commitment to monitor its implementation and to sanction corporations' noncompliance (interview with French human rights organization, 21 August 2019).

In the absence of a formal list of all companies that are subject to this law, French NGOs have collected publicly available data and compiled a provisional list. ${ }^{4}$ Many corporations subject to the law published their first vigilance plans in 2018 and reported

\footnotetext{
${ }^{2}$ Among the main reasons mentioned for opposing the law were the following: that large corporations could exit France as a consequence of the law; that it was inappropriate to adopt such a norm on the domestic level, as solutions should be sought internationally; that the law would cause disproportionate bureaucratic burdens for both the French state and TNCs; and that the law would be too broad and inconsistent (Evans 2019; Petitjean 2019).

${ }^{3}$ The original law proposal can be downloaded at http:/www.assemblee-nationale.fr/14/propositions/ pion1519.asp, and for an English translation of the Duty of Vigilance law, see Sherpa (2019).

${ }^{4}$ This list can be accessed here https://vigilance-plan.org/search/. Accessed 1 November 2019.
} 
on these plans' implementation in 2019 and 2020. French civil society organizations heavily criticized the first generation of vigilance plans, as plans have been very short and "do not enable us to understand precisely which risks have been identified by the businesses [...] and even less how companies respond to them" (Sherpa 2019: 10).

For instance, the 2019 vigilance plan of the French oil and gas company Total, which operates in over 130 countries, is approximately of the length of this article. In Total's plan, in very general terms, the company summarizes activities that fall into a broad category of due diligence. Total refers to the corporation's internal "stakeholder management methodology," which mainly consists of consultation meetings "to build a long-term trusting relationship." Total's "stakeholder management" is supplemented by a network of mediators with local communities. However, as my case study on Bolivia will show, the work of mediators between Total and local communities might not be unproblematic. Intermediaries might, for instance, use "divide and rule" tactics in favor of extractive interests, undermining human rights and indigenous peoples' rights (Schilling-Vacaflor and Eichler 2017; see below). Notably, "indigenous peoples" or "indigenous peoples rights" are not mentioned in Total's vigilance plan. The plan discusses risks in a very general manner, without mentioning specific subsidiaries, controlled companies, or places of production. The plan further refers to Total's internal control mechanisms to verify compliance with the group's requirements on health, society, and the environment. These internal mechanisms mainly build on selfassessment and auditing, but the company also mentions that it established grievance handling procedures and collaborates with independent experts who oversee their human rights and environmental records. The concrete working and effectiveness of such mechanisms merit further investigation.

With reference to an alleged noncompliance with the French Duty of Vigilance law, NGOs already brought two cases against the oil and gas company Total to French courts. ${ }^{6}$ In October 2019, under the leadership of Friends of the Earth France, French and Ugandan NGOs filed a lawsuit against Total. Total plans to drill over 400 oil wells in Western Uganda, many of them in a national park, and to construct a $1445-\mathrm{km}$-long pipeline from Uganda to Tanzania. The claimants argue that the oil activities would lead to the dispossession of up to 50,000 persons, negative health impacts, and a loss of livelihoods and biodiversity (Friends of the Earth, 23 October 2019). Total responded that its subsidiary responsible for the relocation of rural communities in Uganda would constitute an autonomous entity, thereby referring to the "separation principle." At 30 January 2020, the Nanterre High Court declared itself incompetent to take a decision on this case and transferred it to the Commercial Court, whose judges are selected by corporations. Friends of the Earth France commented this decision: "[We] do not understand the judges' reasoning in referring the case to the Commercial Court's jurisdiction [...] it is absurd to believe that corporate representatives elected by their peers are the best judge of a situation where lives and entire ecosystems are threatened!" (Friends of the Earth, 30 January 2020).

\footnotetext{
${ }^{5}$ Total's vigilance plan can be accessed here: https://www.sustainable-performance.total.com/en/reporting/ vigilance-plan. Accessed 13 April 2020.

${ }^{6}$ See https://www.business-humanrights.org/en/france-analysis-on-first-legal-cases-filed-under-enforcementmechanism-set-out-in-duty-of-vigilance-law. Accessed 3 February 2020.
} 


\section{Indigenous Peoples' Rights and Hydrocarbon Extraction in Bolivia: the Case of TOTAL E\&P}

Total E\&P, a Bolivian daughter firm of the French company Total, is one of the hydrocarbon corporations operating in Bolivia. According to the French law, it could now be held accountable in France for any human rights violations or environmental damages caused in Bolivia. Total E\&P has operated in Bolivia since 1994 and focuses on exploration and gas production. The company participates in the mega fields San Antonio, San Alberto, and Itaú, which produce up to 32 million cubic meters of gas per day. ${ }^{7}$ Total E\&P is the main operator in the Ipati and Aquio blocks and processes the hydrocarbons of its fields in the Incahuasi plant. The total area under operation by Total in Bolivia is about 178,000 ha, which represents $6.15 \%$ of all areas under gas extraction in this country (Giné and Villarroel 2011).

In Bolivia, the natural gas sector has become the most important source of revenue for the country's economy (Kohl and Farthing 2012). The Bolivian government under President Evo Morales (2005-2019) significantly increased the state's income from this sector through re-nationalization and high international prices. This process of nationalization has basically consisted of the establishment of new contracts with TNCs like Total E\&P (France), Repsol (Spain), Petrobras (Brazil), British Gas (UK), Pluspetrol (Argentina), and Petroandina SAM (Venezuela). These companies operate as service providers in cooperation with the Bolivian state company Yacimientos Petrolíferos Fiscales Bolivianos (YPFB). Scholars argued that both Bolivia's state and society have been characterized by an "extractive imperative" (Arsel et al. 2016), i.e., the broad conviction that natural resource extraction would be an indispensable motor for development and progress.

The large majority of gas extraction and all activities by Total E\&P have taken place in Bolivia's Chaco region. The Chaco is an ecoregion with a high climatic variability and fragile ecosystems that have been threatened by a decrease of water availability (e.g., Aparicio-Effen et al. 2016). Many projects that explore, exploit, and transport gas in the Chaco overlap indigenous Guaraní territories and the Guaraní have participated in many prior consultation and environmental licensing processes (Schilling-Vacaflor 2017b). Almost all of the activities by Total E\&P are located in Guaraní communities in the department of Santa Cruz, mainly affecting the captaincy Alto Parapeti, where the Ipati and Aquio blocks and the Incahuasi plant were built. There is also a gas duct that was built by Total in 2013 that crosses the captaincy Parapitiguasu.

Total E\&P's behavior and the company's socio-environmental impacts in Guaraní communities have been strongly criticized by indigenous organizations and Bolivian NGOs. The representative Guaraní organization Assembly of Guaraní Peoples (APG) accused Total E\&P for pressuring and bribing indigenous representatives in a prior consultation process about a large-scale seismic exploration project on the Ipati and Aquio blocks in 2007 (Giné and Villarroel 2011). Relatedly, the indigenous communities argued that Total's activities would violate their rights to fair compensation, employment, and water (ibid.). Similar points of critique were raised regarding a highly contested prior consultation process about the construction of the Incahuasi gas plant in

\footnotetext{
${ }^{7}$ See webpage Total in Bolivia: https://www.total.bo/en/explore-and-produce-bolivia. Accessed at 13 April 2020 .
} 
2013 (interview with advisers of Alto Parapeti's communities, 8 November 2013). In April 2013, the APG wrote a letter to the Ministry of Hydrocarbons and Energy, requesting to stop this participation process. ${ }^{8}$ In this letter, the indigenous organization argued that Total E\&P had already carried out new activities in Guaraní territories without prior consultation. The communities also accused Total to pay inadequate compensation and to break existing investment promises.

Guaraní captaincies have usually been quite stable political entities that are based on the holding of joint collective land titles, called Tierras Comunitarias de Origen (TCOs). However, in the cases of the captaincies Alto Parapetí and Parapitiguasu, the activities carried out by Total E\&P have contributed to exacerbate existing tensions between local communities, and in both cases, some communities split and founded a new captaincy. In Alto Parapeti, community members argued that Total's privileging of communities located close by the company's activities contributed to the separation of more distant communities that felt excluded from the circulation of benefits (see Schilling-Vacaflor and Eichler 2017). In the case of Parapitiguasu, the communities living close to Total's gas pipeline split from their previous captaincy. Community members argued that Total encouraged these communities to negotiate with the company exclusively (interviews with community members, September to November 2013). Such corporate practices of "divide and rule" tend to undermine the own norms and procedures of indigenous peoples and contribute to internal divisions and conflicts as well as to a weakening of indigenous organizations. In the long run, weak and divided organizations have a reduced capacity to defend their claims, to organize collective action, and, ultimately, to uphold their rights.

In February 2014, indigenous communities from the captaincy Alto Parapeti mobilized and blockaded a street to protest against Total, on the grounds that "the company has systematically misrecognized our rights and their functionaries have used diverse ploys to divide our community organizations and to evade their obligations according to Bolivia's constitution and domestic laws." The company's mediators with local communities that should help to protect human rights according to Total's vigilance plan (see above) were strongly criticized for disrespecting local norms and procedures. Furthermore, not only did police forces repress the communities' protest, but community members also narrated that staff employed by Total bribed their leaders in order to get them to abstain from future collective action against the company (SchillingVacaflor and Eichler 2017).

In summary, the collected data suggest that Total E\&P in Bolivia might have violated human rights and rights of indigenous peoples, such as those stipulated in the International Labor Organization Convention 169 on indigenous and tribal peoples (International Labor Organization Convention 169, 1989; ILO C169). For instance, Total's "divide and rule" practices were reported to hinder prior consultation processes in good faith (articles 6 and 15 of ILO C169) and to work against the "promotion of the full realization of the social, economic and cultural rights of these peoples with respect for their social and cultural identity, their customs and traditions and their institutions" (article 2.2b of ILO C169; see also article 8 of ILO C169). Indigenous communities

\footnotetext{
${ }^{8}$ APG Capitanía Alto Parapeti (18 April 2013). Proceso de Consulta y Participación proyecto "Desarrollo y Explotación Campo Incahuasi (Bloque Incahuasi) y Campo Aquio (Bloque Ipati).”

9 Asamblea del Pueblo Guaraní, 28 February 2014. Open letter to President Evo Morales.
} 
have also repeatedly expressed the view that they did not receive fair compensation for damages caused by Total's projects, despite the fact that article 15.2 of ILO C169 stipulates that "[...] The peoples concerned shall wherever possible participate in the benefits of such activities, and shall receive fair compensation for any damages which they may sustain as a result of such activities." Moreover, Total's activities allegedly violated the Guaraní communities' rights to water and employment (Giné and Villarroel 2011). It is, however, unclear whether the grievances brought forward by indigenous organizations and Bolivian NGOs against Total would be classified as human rights violations by a court in case that a lawsuit would be filed.

Bolivia has assumed a pioneering role regarding the recognition of indigenous peoples' rights, by not only ratifying ILO C169, but also adopting the United Nations Declaration on the Rights of Indigenous Peoples (UNDRIP) as domestic law in October 2007. Bolivia's 2009 constitution declares the state as being "plurinational" and recognizes comprehensive indigenous peoples' rights. Nevertheless, due to the strong dependence of Bolivia's economy on the export of natural gas and to the extractivist orientation of the state, it has been very challenging or even impossible for Guaraní communities to claim their rights (Humphreys Bebbington 2012). The ample support of Bolivia's neo-extractivist regime has shaped power relations in the country in favor of extractivist agendas and to the disadvantage of the indigenous right to self-determined development and environmental protection. These power asymmetries have also manifested clearly in the relations among different state institutions. For example, Bolivia's environmental and human rights institutions are weak, compared to the powerful Ministry of Hydrocarbons and Energy or the Ministry of Economy and Finance (Schilling-Vacaflor 2017a). Bolivia's judiciary and even the Bolivian Ombudsperson have become increasingly subordinated to political influences (see Verdugo 2017). The Guaraní communities have used different judicial and political means to bring attention to their claims, but these actions have remained largely unsuccessful (SchillingVacaflor 2017b).

Due diligence regulations from home state countries could be of particular relevance for such cases where host state countries do not live up to their obligations to enforce the human rights duties of TNCs in their jurisdictions. Accordingly, I share the position of the United Nations Committee on the Rights of the Child that home state and host state regulations in the ambit of human rights are complementary (cit. after Krajewski 2018: 117). In the following section, I will discuss more in detail to what extent new rules like the French Duty of Vigilance law could contribute to harden corporate accountability and help to address negative socio-environmental impacts like the ones outlined above.

\section{The Duty of Vigilance Law and Total E\&P in Bolivia: Advances, Limitations, and Challenges}

The French Duty of Vigilance law has become a model for new due diligence policies in the EU with the aim of regulating global commodity chains and for enhancing foreign corporate accountability. This law obligates TNCs like Total to present their vigilance plans on a yearly basis, including the report of actions and impacts of their daughter firms. In consequence, French mother firms might increase their efforts to 
control subsidiaries along their supply chains. While the "separation principle" has allowed TNCs to dissociate from the harms caused by their daughter firms or controlled companies, now at least in France, parent companies, facing increased reputational risks and legal liability, might become more responsive to the concerns and needs of workers and local communities in the Global South. Hence, in the future, the mother firm Total might increasingly act upon local grievances such as the ones repeatedly expressed by Guaraní communities from Bolivia regarding the actions and impacts caused by Total's subsidiary. Human rights organizations that have had yearlong experiences with tort-based litigation cases against TNCs hope that due diligence regulations will contribute to a systematic improvement of corporations' human rights and environmental performance (interviews with French and German human rights organizations, 21 August 2019 and 4 July 2019).

However, the question of whether and under which conditions new due diligence policies will actually lead to concrete improvements remains to be studied empirically in different sectors and places. With reference to my French-Bolivian case study, I argue that the effectiveness of the French law to prevent and address negative externalities abroad will depend on the dynamic interaction between developments in the home state and in host state countries.

In France, the government has not (yet?) taken up its responsibility to rigorously monitor and to enforce the implementation of the law. This problem seems to be of a more general and systemic nature. Previous studies on different kinds of due diligence policies similarly found that home states of TNCs have lacked important human resources and political will as well as relevant information to supervise global supply chains in a rigorous manner (Moser and Leipold 2019; Partzsch 2020; see "Hardening Corporate Accountability through Due Diligence Policies?"). In the absence of state action, French civil society organizations have assumed the task to monitor the implementation of the Duty of Vigilance law, by analyzing the quality of vigilance plans and by collecting reliable information about the negative externalities of TNCs abroad (interview with French human rights organization, 21 August 2019). The existence of the French law has contributed to closer alliances between human rights and environmental NGOs within France and between civil society actors from France and from places in the Global South (ibid). Given the limitations of the first generation of vigilance plans that lack specificity and verifiability, the NGO Sherpa (2019) released a vigilance plans reference guidance to outline how corporations can operationalize and implement their human rights duty of vigilance in a better way. Similarly, scholars like Smit et al. (2020) showcase good practice examples of corporations' due diligence systems while at the same time outlining that in general there is still much room for improvement.

It remains to be seen whether and to what extent TNCs like Total will be willing to act and to increasingly take their "duty of care" obligations seriously. Substantial institutional, discursive, and practical changes in the parent companies of TNCs could open up new opportunities for local actors in the Global South, such as Bolivia's Guaraní communities to press for change. However, we cannot expect corporations to change voluntarily. Rather, sustained civil society mobilization and the development of institutional environments in home state countries, which are able to effectively control the implementation and enforcement of new mandatory measures regulating global supply chains, will be necessary. NGOs already filed the first lawsuits to French courts. Indeed, the first litigation case whereabout a decision is pending addresses oil projects operated by Total in Uganda and their impacts on 
local communities. It will now be up to the judicial branch to decide upon important political questions. While the Duty of Vigilance law undoubtedly represents an important step to challenge the "separation principle" and to allow claimants from abroad to settle their cases in French courts, other problems that have plagued previous tort action claims have not yet been resolved. As the burden of proof was shifted from the companies to the victims in the process of adopting the French law, it will be a major hurdle for claimants to provide evidence for sustaining their accusations.

The Bolivian case is a good example for reflecting upon this challenge. In the Bolivian case presented here, the following questions would probably come to the front in a possible court case: How can the communities from Alto Parapetí and Parapitiguasu prove that Total has divided and weakened its social organizations? or How to prove the causality between the use of "divide and rule" tactics by Total E\&P's employees in Bolivia and a lack of the duty of care by the mother company?

Previous research in the field of political ecology into contestations over different forms of knowledge in the Bolivian hydrocarbon region has emphasized the wide power asymmetries between the technical "corporate science" (Kirsch 2014) reproduced by oil and gas companies on the one hand and the local and experiential knowledge held by local populations on the other (Schilling-Vacaflor 2017b). It has been very difficult or even impossible for Guaraní communities to prove in prior consultation and environmental licensing processes that they have been negatively affected by hydrocarbon projects in their territories. Similarly, as outlined in "Tort-Based Litigation Against TNCs, the PRR Framework, and the UNGPs," it has represented an important barrier for claimants in many tort-based cases to tip the power balance of existing knowledge asymmetries. There have been many contestations regarding the question of what constitutes a valid evidence and how to prove the causality between the practices of the headquarters of TNCs and local impacts in distant places. For instance, due to challenges regarding issues like the burden of proof and causality, Terwindt et al. (2018) explained that in litigation cases regarding the impacts of pesticide trade, human rights lawyers decided to focus on flawed labeling instead of the actual impacts of pesticide pollution. Similarly, an interviewee from a German human rights NGO explained that they have not yet led litigation cases concerning land rights because of difficulties to collect clear and convincing evidence on this issue (interview, 4 July 2019).

It would thus be a precondition for presenting a potentially successful case on the impacts of Total's projects in Bolivia to a French court to first gather solid evidence in order to substantiate community grievances and complaints. The collection of solid evidence on issues like bribery or the division of local communities would be particularly challenging. In addition, in case that such evidence can be collected, it is questionable whether a court would interpret the identified impacts as human rights violations. It is also difficult to appraise in advance whether a court would agree with local communities that compensation payments by Total E\&P have been inadequately low. Bolivia's Guaraní communities, supported by local universities and the Canadian development agency, have established their own socioenvironmental monitoring systems to observe the impacts caused by hydrocarbon companies, data that could be used to sustain the communities' claims. This system could be further enhanced, for instance by including the use of new technologies offered by smartphones, drones, GIS systems, etc. (see Mena et al. 2020). Irrespective of such important efforts, based on previous experiences with tort-based litigation and other situations in which community knowledge has challenged corporate-dominated politics of knowledge (e.g., 
Silva-Castañeda 2012; Enneking 2019), we can expect that the highly skilled teams of lawyers of TNCs would not easily be defeated in court.

In Bolivia's Chaco region, Guaraní communities have increasingly suffered from temporary water scarcity and argue that the gas activities from corporations like Total contribute to a reduction of water in the region. However, more comprehensive data on water resources and on the factors responsible for decreasing water levels are missing, and it has been challenging to evaluate the specific impacts of gas projects led by different companies. The contribution of gas activities to a loss of access to water by Guaraní communities can be understood as a form of "slow violence," which is violence that "appears gradually and out of sight, a violence of delayed destruction that is disbursed across time and space, an attritional violence that is typically not viewed as violence as all" (Nixon cit. after Dehm 2020). As Dehm (2020) has shown with reference to the attempts to hold TNCs accountable for their impacts on climate change, it has been extremely difficult to give legal meaning and significance to such situations of slow violence. The question of whether and how due diligence regulations could help to hold corporations accountable for instances of slow violence, which are deteriorating the human rights and environmental conditions of many vulnerable persons and collectivities worldwide, merits increased attention and scholarly research.

\section{Conclusion}

The adoption of the French Duty of Vigilance law has been a remarkable advance for increasing foreign corporate accountability. The law challenges the "separation principle," comprises both human rights and environmental obligations, and establishes a regime of legal liability. Nevertheless, this article argues that the law is just a starting point for hardening foreign corporate accountability. Its effectiveness to address negative externalities along global commodity chains will depend on processes in home state and host state countries of TNCs. Corporations still have a long way to go to establish adequate due diligence systems, while home states have not yet been able and/or willing to thoroughly monitor TNCs located in their jurisdiction and to sanction noncompliance. In addition, this study emphasizes that the politics of knowledge that are embedded in highly asymmetrical constellations of power represent a major hurdle, both in relation to corporate reporting and to litigation cases against TNCs. Powerful TNCs tend to exercise their obligations of a duty of care in a way that suits their own interests and to produce knowledge that conceals any negative impacts caused or exacerbated by their businesses. Local communities and NGOs will need to put much energy and resources into the production of knowledge and the collection of solid evidence for challenging company discourses and "corporate science" when aiming to proof any breach of the duty of care.

Based on my French-Bolivian case study, I argue that future research should keep an eye on contestations regarding the operationalization and use of new due diligence regulations. The effective implementation of mandatory supply chain regulations will thus largely depend on the question of whether a more equal playing field between civil society actors, states, and corporations (from the Global North and the Global South) can be created and whether home state countries will be willing and able to actually monitor and sanction TNCs located in their jurisdictions. Ultimately, the concrete experiences of vulnerable actors in the hundreds of thousands of locations worldwide 
that are involved in or affected by global commodity chains will be decisive for answering the question of how meaningful and effective due diligence policies in the ambit of business and human rights actually are.

Funding Open Access funding enabled and organized by Projekt DEAL. This work was supported by the Deutsche Forschungsgemeinschaft (DFG) under grant no. LE 2396/4-1 through the project "GOVERNECT Governance of Environmental Sustainability in Telecoupled Systems of Global Inter-Regional Connectedness."

\section{Compliance with Ethical Standards}

Conflict of Interest The author declares that he/she has no conflict of interest.

Open Access This article is licensed under a Creative Commons Attribution 4.0 International License, which permits use, sharing, adaptation, distribution and reproduction in any medium or format, as long as you give appropriate credit to the original author(s) and the source, provide a link to the Creative Commons licence, and indicate if changes were made. The images or other third party material in this article are included in the article's Creative Commons licence, unless indicated otherwise in a credit line to the material. If material is not included in the article's Creative Commons licence and your intended use is not permitted by statutory regulation or exceeds the permitted use, you will need to obtain permission directly from the copyright holder. To view a copy of this licence, visit http://creativecommons.org/licenses/by/4.0/.

\section{References}

Addo MK (2014) The reality of the United Nations guiding principles on business and human rights. Human Rights Law Review 14(1):133-147.

Aïssi E (2018) The French duty of vigilance law: a new legal instrument for a fairer globalization. Global Labour Column 311.

Arsel M, Hogenboom B, Pellegrini L (2016) The extractive imperative in Latin America. The extractive industries and society 3(4):880-887.

Aparicio-Effen M, Arana I, Aparicio J et al (2016) Climate change and health vulnerability in Bolivian Chaco Ecosystems. Climate Change and Health. https://doi.org/10.1007/978-3-319-24660-4_14.

Bartley T (2014) Transnational governance and the re-centered state: Sustainability or legality? Regulation \& Governance 8(1): 93-109.

Bebbington A, Bury J (2013) Subterranean struggles: New dynamics of mining, oil, and gas in Latin America. University of Texas Press, Texas.

Boyle A (2012) Human rights and the environment: Where next? European Journal of International Law 23(3):613-642.

Brabant S, Savourey E (2017) France's corporate duty of vigilance law: A closer look at the penalties faced by companies. Revue Internationale De La Compliance Et De L’éthique Des Affaires 50.

Bradshaw C (2020) Corporate Liability for Toxic Torts Abroad: Vedanta v Lungowe in the Supreme Court. Journal of Environmental Law 32(1):139-150.

Bridge G, Le Billon P (2017) Oil. John Wiley \& Sons, New Jersey.

Cashore B, Auld G, Newsom D (2004) Governing through Markets. Forest Certification and the Emergence of Non-state Authority. Yale University Press, New Haven.

Clapp J (2005) Global environmental governance for corporate responsibility and accountability. Global Environmental Politics 5(3):23-34.

Clapp J (2018) Mega-mergers on the menu: corporate concentration and the politics of sustainability in the global food system. Global Environmental Politics 18(2):12-33.

Cossart S, Chaplier J, de Lomenie TB (2017) The French law on duty of care: A historic step towards making globalization work for all. Business and Human Rights Journal 2(2):317-323.

Cottier T, Pauwelyn J, Bürgi E (2005) Human rights and international trade. Oxford University Press, Oxford. Craig G (2017) The UK's modern slavery legislation: an early assessment of progress. Social Inclusion 5(2):16-27. 
Dauvergne P (2010) The shadows of consumption: Consequences for the global environment. MIT press, Massachusetts.

Dauvergne P, Lister J (2012) Big brand sustainability: Governance prospects and environmental limits. Global Environmental Change 22(1):36-45.

Dehm J (2020) Climate change, 'slow violence'and the indefinite deferral of responsibility for 'loss and damage'. Griffith Law Review, online first. https://doi.org/10.1080/10383441.2020.1790101

Eckersley R (2004) The big chill: The WTO and multilateral environmental agreements. Global Environmental Politics 4(2):24-50.

Enneking LF (2019) Transnational human rights and environmental litigation: a study of case law relating to shell in Nigeria. In Feichter I, Krajewski M, Roesch R (eds) Human Rights in the Extractive Industries. Springer, Cham, pp. 511-551.

Evans A (2019) Overcoming the global despondency trap: strengthening corporate accountability in supply chains. Review of International Political Economy. https://doi.org/10.1080/09692290.2019.1679220.

Friends of the Earth (23 October 2019) Oil company Total faces historic legal action in France for human rights and environmental violations in Uganda. https:/www.foei.org/news/total-legal-action-francehuman-rights-environment-uganda Accessed 12 March 2020.

Friends of the Earth (30 January 2020) Total abuses in Uganda: French High Court of Justice declares itself incompetent in favour of the Commercial Court. https://www.foei.org/no-category/total-abuses-ugandafrench-high-court-of-justice-declares-itself-incompetent-duty-vigilance-law Accessed 12 March 2020.

Fuchs D, Kalfagianni A, Havinga T (2011) Actors in private food governance: the legitimacy of retail standards and multistakeholder initiatives with civil society participation. Agriculture and human values 28(3):353-367.

Gilbert J (2012) Corporate accountability and indigenous peoples: prospects and limitations of the US Alien Tort Claims Act. International Journal on Minority and Group Rights 19(1): 25-52.

Giné J, Villarroel F (2011) 'TOTAL E\&P Bolivie y sus Impactos en los Derechos Humanos del Pueblo Guaraní de la Capitanía de Muyupampa'. CEADESC, Santa Cruz.

Grant RW, Keohane RO (2005) Accountability and abuses of power in world politics. American political science review 99(1):29-43.

Humphreys Bebbington D (2012) Consultation, Compensation and Conflict: Natural Gas Extraction in Weenhayek Territory, Bolivia. Journal of Latin American Geography 11(2):49-71.

IPCC (2014) Climate Change 2014: Mitigation of Climate Change. Contribution of Working Group III to the Fifth Assessment Report of the Intergovernmental Panel on Climate Change. Cambridge University Press, Cambridge.

Kirsch S (2014) Mining capitalism: The relationship between corporations and their critics. Univ. of California Press, California.

Kohl B, Farthing L (2012) Material Constraints to Popular Imaginaries: The Extractive Economy and Resource Nationalism in Bolivia. Political Geography 31(4):225-235.

Krajewski M (2018) Regulierung transnationaler Wirtschaftsbeziehungen zum Schutz der Menschenrechte: Staatliche Schutzpflichten jenseits der Grenze? In: Krajewski M (ed) Staatliche Schutzpflichten und unternehmerische Verantwortung für Menschenrechte in globalen Lieferketten. FAU University Press, Erlangen, pp. 97-140.

LeBaron G, Lister J, Dauvergne P (2017) Governing Global Supply Chain Sustainability through the Ethical Audit Regime. Globalizations 14 (6):958-975.

Leifsen E, Gustafsson MT, Guzmán-Gallegos MA et al (2017) New mechanisms of participation in extractive governance: between technologies of governance and resistance work. Third World Quarterly 38(5):1043-1057.

Lenschow A, Newig J, Challies E (2016) Globalization's limits to the environmental state? Integrating telecoupling into global environmental governance. Environmental Politics 25(1):136-159.

Mares R (2020). Liability within corporate groups: Parent company's accountability for subsidiary human rights abuses. In: Deva S (ed.) Research Handbook on Human Rights and Business. Edward Elgar, Cheltenham. https://doi.org/10.2139/ssrn.3481052

Mena CF, Arsel M, Pellegrini L et al (2020) Community-Based Monitoring of Oil Extraction: Lessons Learned in the Ecuadorian Amazon. Society \& Natural Resources 33(3):406-417.

Moser C, Leipold S (2019) Toward "hardened" accountability? Analyzing the European Union's hybrid transnational governance in timber and biofuel supply chains. Regulation \& Governance. https://doi.org/ 10.1111/rego. 12268

O'Brien CM, Mehra A, Blackwell S et al (2016) National action plans: Current status and future prospects for a new business and human rights governance tool. Business and Human Rights Journal 1(1):117-126.

OECD (2018) Multinational enterprises in the global economy. Heavily debated but hardly measured. At: https://www.oecd.org/industry/ind/MNEs-in-the-global-economy-policy-note.pdf (Accessed 09 July 2020). 
Partzsch L (2020) Alternatives to Multilateralism: New Forms of Social and Environmental Governance. MIT Press, Massachusetts.

Palombo D (2019) The duty of care of the parent company: A comparison between French law, UK precedents and the Swiss proposals. Business and Human Rights Journal 4(2):265-286.

Petitjean O (2019) Devoir de vigilance. Une victorie contre l'impunité des multinationals. Charles Léopold Mayer, Paris.

Rivera HC (2019) National Action Plans on Business and Human Rights: Progress or Mirage? Business and Human Rights Journal 4(2):213-237.

Ruggie JG (2018) Multinationals as global institution: Power, authority and relative autonomy. Regulation \& Governance 12(3):317-333.

Schilling-Vacaflor A (2017a) 'If the company belongs to you, how can you be against it?' Limiting participation and taming dissent in neo-extractivist Bolivia. The Journal of Peasant Studies 44(3):658-676.

Schilling-Vacaflor A (2017b) Who controls the territory and the resources? Free, prior and informed consent (FPIC) as a contested human rights practice in Bolivia. Third World Quarterly 38(5):1058-1074.

Schilling-Vacaflor A, Eichler J (2017) The Shady Side of Consultation and Compensation: 'Divide-and-Rule' Tactics in Bolivia's Extraction Sector. Development and Change 48(6): 1439-1463.

Schilling-Vacaflor A, Lenschow A, Challies E et al (forthcoming) Contextualizing Certification and Auditing: Soy Certification and Access of Local Communities to Land and Water in Brazil. World Development.

Schleifer P, Fiorini M, Fransen L (2019) Missing the bigger picture: a population-level analysis of transnational private governance organizations active in the global South. Ecological Economics 164:106362.

Shamir R (2004) Between self-regulation and the Alien Tort Claims Act: On the contested concept of corporate social responsibility. Law \& Society Review 38(4):635-664.

Sherpa (2019) Vigilance Plans Reference Guidance. Sherpa, Paris.

Sikor T, Auld G, Bebbington, AJ (2013) Global land governance: from territory to flow? Current Opinion in Environmental Sustainability 5(5):522-527.

Silva-Castañeda L (2012) A forest of evidence: third-party certification and multiple forms of proof - a case study of oil palm plantations in Indonesia. Agriculture and Human Values 29(3):361-370.

Simons P (2012) International law's invisible hand and the future of corporate accountability for violations of human rights. Journal of Human Rights and the Environment 3(1):5-43.

Smit L, Holly G, McCorquodale R et al (2020) Human rights due diligence in global supply chains: evidence of corporate practices to inform a legal standard. The International Journal of Human Rights, online first. https://doi.org/10.1080/13642987.2020.1799196

Terwindt C, Morrison SG, Schliemann C (2018) Health Rights Impacts by Agrochemical Business: Legally Challenging the Myth of Safe Use. Utrecht J. Int'1 \& Eur. L. 34:130.

Terwindt C, Saage-Maaß M (2016) Liability of Social Auditors in the Textile Industry. International Policy Analysis. ECCHR/Friedrich-Ebert-Stiftung, Berlin.

Verdugo S (2017) How the Bolivian Constitutional Court Helped the Morales Regime to Break the Political Insurance of the Bolivian Constitution. Int'l J. Const. L. Blog, at: http://www.iconnectblog.com/2017/12/ how-the-bolivian-constitutional-court-helped-the-morales-regime-to-break-the-political- insurance-of-thebolivian-constitution/

Wesche P, Saage-Maaß M (2016) Holding companies liable for human rights abuses related to foreign subsidiaries and suppliers before german civil courts: Lessons from Jabir and Others v KiK. Human Rights Law Review 16(2):370-385.

Zajak, S, Scheper C (2019) The dual nature of transparency: Corporatization and democratization of global production networks. In: Berger S, Owetschkin D (eds) Contested Transparencies, Social Movements and the Public Sphere. Palgrave Macmillan, Cham, pp. 211-232.

\section{Legal Sources}

Auroi D et al. (6 November 2013). Proposition de loi relative au devoir de vigilance des sociétés mères et des entreprises donneuses d'ordre. $\mathrm{N}^{\circ} 1519$. Asamblée Nationale. http://www.assemblee-nationale.fr/14/ propositions/pion1519.asp Accessed 12 April 2020.

Dutch Child Labor Due Diligence Law (2019).

EU Conflict Minerals Regulation (2017). Regulation 2017/821.

EUTR (2010). European Union Timber Regulation. Regulation (EU) No 995/2010.

EU-RED (2009). EU Renewable Energy Directive 2009/28/EC.

International Labor Convention 169 (1989). Indigenous and Tribal Peoples Convention.

IUU regulation (2008). European Union Regulation on Illegal, Unreported, and Unregulated (IUU) Fishing. Regulation (EC) No 1005/2008. 
Law No. 2017-399 (27 March 2017). Duty of Vigilance of Parent and Instructing Companies. France. PRR framework (2008). United Nations Protect, Respect, and Remedy framework.

UK Modern Slavery Act (2015).

United Nations Human Rights Office of the High Commissioner (2011). Guiding Principles on Business and Human Rights. New York and Geneva: United Nations.

Publisher's Note Springer Nature remains neutral with regard to jurisdictional claims in published maps and institutional affiliations. 